\title{
Moths (Insecta: Lepidoptera) of Jambudwip Island, Sundarban Biosphere Reserve, India: a Preliminary Report
}

\section{Olive Biswas ${ }^{1}$, Suresh Kr. Shah ${ }^{2}$, Balaram Panja3 ${ }^{3}$ Apurva Das², Biplob Kr. Modak4*, Bulganin Mitra5}

'South 24-Parganas, CMOH Office, M.R. Bangur Hospital Complex, Kolkata-700033, West Bengal, India

${ }^{2} Z$ Zoological Survey of India, M-Block, New Alipore, Kolkata700053, West Bengal, India

${ }^{3}$ Purba Medinipur Forest Division, Chak Kamina, Tamluk, Purba Medinipur-721625, West Bengal, India

${ }^{4}$ Department of Zoology, Sidho Kanho Birsha University, Purulia, 723104, West Bengal, India

${ }^{5}$ Department of Zoology, Ramakrishna Mission Vivekananda Centenary College, Rahara, Kolkata-70o118, W.B., India

Key words: Mangroves

Study area: Sunderban, West Bengal

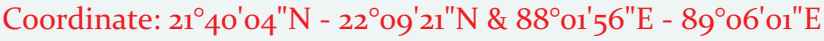

\section{Introduction:}

The Indian part of Sundarban covers covering about 9,630 square kilometres area is a unique habitat harbours about 90 species of mangrove plants inclusive of True mangroves, back mangroves and associated mangroves (Saha \& Mitra, 2017). Sundarban Biosphere Reserve (SBR) harbours 2626 species of fauna including 210 species of Lepidoptera (Chandra et al., 2017). However, knowledge of mangrove inhabiting moths is very scanty in India (Mitra et al., 2019). In the recent past, studies (Cannicci et al. 2008) revealed that the biotic factors (including insects) are also important to maintain the vegetation structure and ecological processes occurring in the mangrove ecosystem. Insect surveys in mangroves of India have proved that association of Lepidoptera with these unique plants is restricted to few species as compared to their huge diversity. Total 200 species of moths belonging to 169 genera under 25 families have been found to occur in the Indian mangroves (Mitra et al., 2019).

Mitra (2017) documented 210 species under 161 genera belonging to 24 families of Lepidoptera from the islands (both mangroves and non-mangroves) of Sundarban Biosphere Reserve. Out of them, 95 species under 8 o genera belonging to 18 families were moths and 115 species under 81 genera belonging to 06 families were butterflies. Since the

\section{Abstract}

Jambudwip is an uninhabited island in the Indian part of Sundarban Biosphere Reserve (SBR), having particularly mangrove plants. A faunal survey was conducted during November 2016 at Jambudwip which has resulted in 27 species of moths under 24 genera belonging to 11 families reported for the first time exclusively from the mangroves of Jambudwip Island. The species composition of Jambudwip has been compared with nearby located five islands of SBR namely Sagar, Gosaba, Jharkhali, Bali and Satjelia which indicated maximum similarity with Jharkhali Island. information on mangrove inhabiting moths of Sundarban Biosphere Reserve is limited, so an attempt has been taken to document the moth species residing exclusively in the mangrove vegetation of Jambudwip Island. Present communication reports 27 species belonging to 24 genera under 11 families of moths from the mangroves of Jambudwip Island.

\section{Methodology:}

Study area: Jambudwip is situated in the extreme southwest of SBR, in the confluence of Muriganga river and Bay of Bengal. The isolated and secluded island is small/moderate in size covering an area of 1950 hectares and harbours mangrove floral species like Avicennia alba, Excoecaria agallocha, Bruguiera spp., Avicennia marina, Aegiceras cornniculatum, Aegialitis rotundifolia, Ceriops decandra, Sonneratia apetala, and Rhizophora apiculata etc. The island is declared as Reserved Forest vide Notification No. 7737 - for dated 29th May, 1943. It is presently under the administrative jurisdiction of South 24 Parganas Forest Division.

Sampling methodology: during November 2016, faunal survey was carried out at Jambudwip which is located between geo coordinates $21^{\circ} 34^{\prime} 51.53^{\prime \prime} \mathrm{N}$ latitude and $88^{\circ} 10^{\prime} 58.01^{\prime \prime}$ E longitude. Adult moths were collected at

*Corresponding Author: bkmodakog@gmail.com 


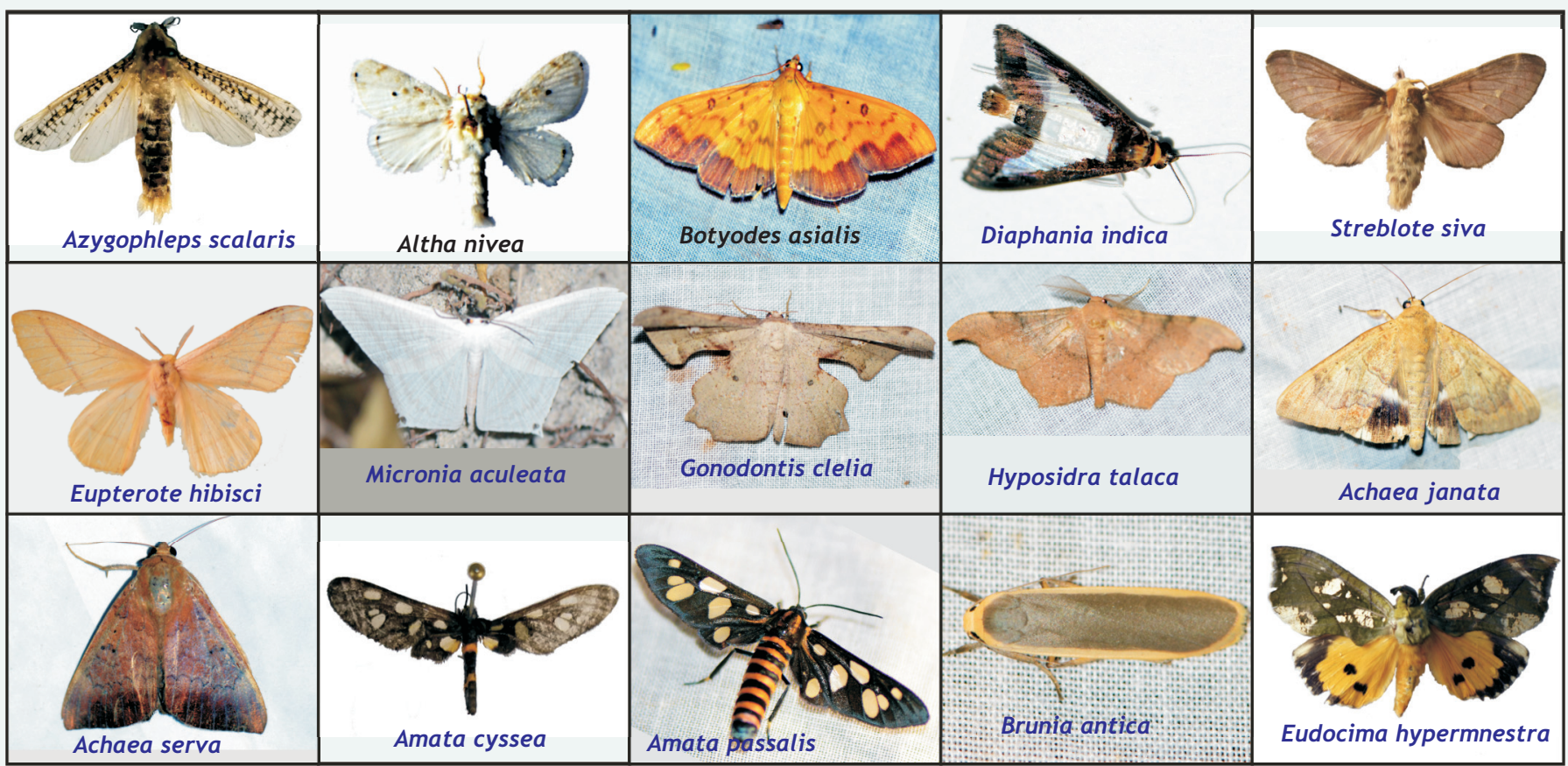

Plate 1. Moths recorded from Jambudwip, Sundarbans, West Bengal

night from 6.00 p.m. to 4.00 a.m., with the help of a light trap composed of 27 Watt Philips energy saver CFL Lamp illuminated in front of a vertical white cloth sheet measuring approximately $3 \times 2 \mathrm{~m}$. Photographs were taken by using Nikon D7ooo camera. The collected specimens have been processed and preserved by following methods described by Arora (1986). The specimens will be deposited in the Zoological Survey of India.

Identification: standard literature (Hampson 1892, 1894, 1895, 1896 and Holloway 1988, 1999, 2001) have been followed. Leica EZ4 and Leica EZ4 HD microscopes were used for specimen identification. Scientific names of the specimens were validated following the database of the Natural History Museum (Source: www.nhm.ac.uk/ourscience/data/lepindex). The cluster analysis of species composition has been done using the software PAST, accessed on dated 20/01/2019 (Fig.-1).

\section{Results \& Discussion:}

Total 27 species belonging to 24 genera under 11 families of

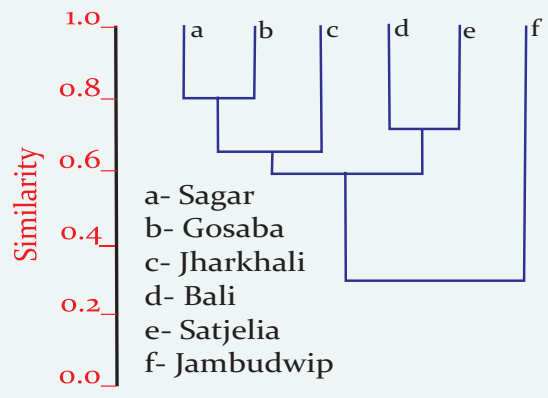

Figure-1: Cluster analysis of species composition among different islands of SBR

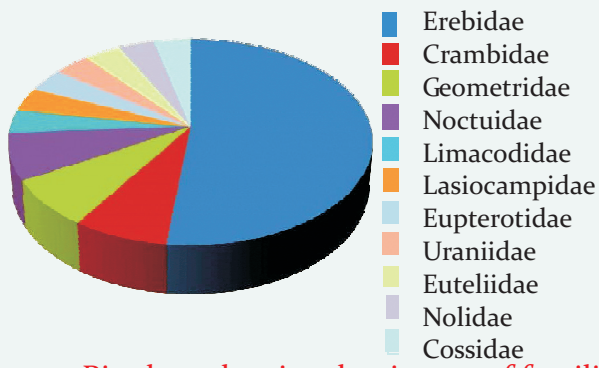

Figure-2: Pie chart showing dominance of families.

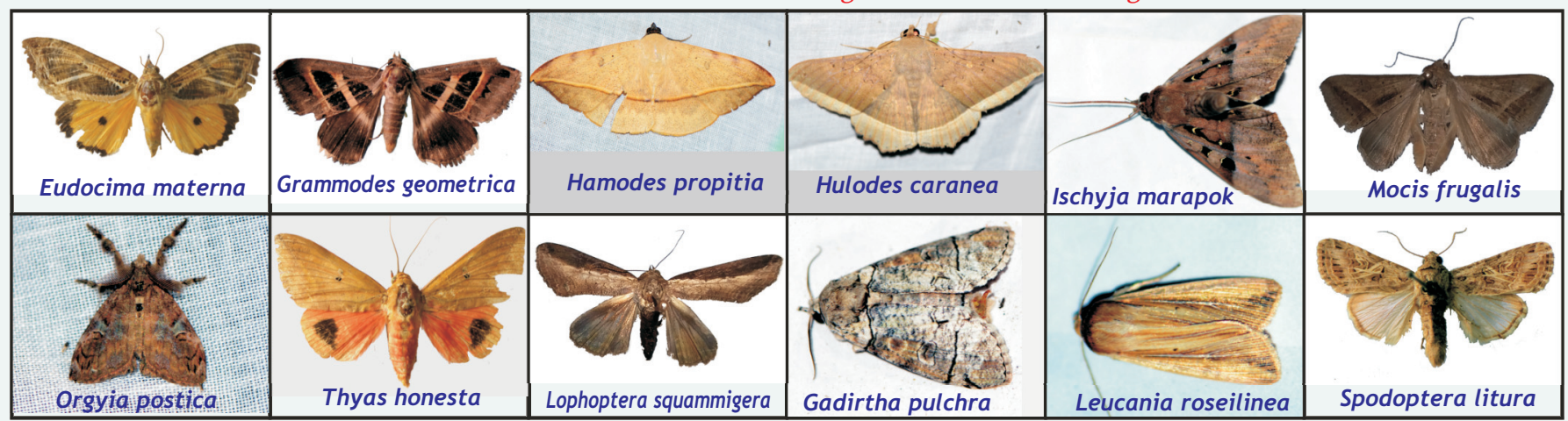

Plate 2. Moths recorded from Jambudwip, Sundarbans, West Bengal (Cont.) 
Table.1. Distribution of Moth species recorded from Jambudwip and nearby Islands and also reports outside the present study.

\begin{tabular}{|c|c|c|c|c|c|}
\hline \multirow[t]{2}{*}{ Name } & \multicolumn{4}{|c|}{$\begin{array}{l}\text { In other Islands } \\
\text { of SBR }\end{array}$} & \multirow{2}{*}{$\begin{array}{l}\text { In other } \\
\text { mangroves } \\
\text { of India }\end{array}$} \\
\hline & 1 & 2 & 34 & 5 & \\
\hline $\begin{array}{c}\text { Azygophleps scalaris Cossidae } \\
\text { (Fabricius, 1775) }\end{array}$ & - & - & +- & - & SBR \\
\hline $\begin{array}{c}\text { Botyodes asialis Crambidae } \\
\text { Guenée, } 1854\end{array}$ & - & - & - & - & SBR \\
\hline $\begin{array}{c}\text { *Diaphania indica Crambidae } \\
\text { (Saunders, 1851) }\end{array}$ & + & + & ++ & + & SBR \\
\hline $\begin{array}{c}\text { Micronia aculeata Uraniidae } \\
\text { Guenée, } 1857\end{array}$ & - & - & $-\quad-$ & - & SBR \\
\hline $\begin{array}{c}\text { Achaea janata Erebidae } \\
\text { (Linnaeus, 1758) }\end{array}$ & + & - & -- & - & $\begin{array}{l}\text { SBR, Gujarat, } \\
\text { And. \& Nico. }\end{array}$ \\
\hline $\begin{array}{c}\text { Achaea serva Erebidae } \\
\text { (Fabricius, 1775) }\end{array}$ & - & - & - & - & SBR \\
\hline $\begin{array}{c}\text { Amata cyssea Erebidae } \\
\text { (Stoll, }[1782])\end{array}$ & + & + & ++ & + & SBR \\
\hline $\begin{array}{c}\text { *Amata passalis Erebidae } \\
\text { (Fabricius, 1781) }\end{array}$ & + & + & ++ & + & $\begin{array}{l}\text { SBR, Tamil } \\
\text { Nadu, Kerala, } \\
\text { Karnataka }\end{array}$ \\
\hline $\begin{array}{c}\text { Brunia antica Erebidae } \\
\text { (Walker, 1854) }\end{array}$ & - & - & - & - & SBR \\
\hline $\begin{array}{l}\text { Eudocima- } \quad \text { Erebidae } \\
\text { hypermnestra (Stoll, 1780) }\end{array}$ & - & - & - & - & SBR \\
\hline $\begin{array}{c}\text { Eudocima materna Erebidae } \\
\text { (Linnaeus, 1767) }\end{array}$ & - & - & $-\quad-$ & - & SBR \\
\hline $\begin{array}{l}\text { Grammodes- } \quad \text { Erebidae } \\
\text { geometrica (Fabricius, 1775) }\end{array}$ & + & + & -+ & - & SBR \\
\hline $\begin{array}{l}\text { Hamodes propitia Erebidae } \\
\text { (Guérin-Méneville, [1831] }\end{array}$ & - & - & - & - & SBR \\
\hline $\begin{array}{c}\text { Hulodes caranea Erebidae } \\
\text { (Cramer, [178o]) }\end{array}$ & - & - & - & - & SBR \\
\hline $\begin{array}{c}\text { Ischyja marapok Erebidae } \\
\text { Holloway, } 2005\end{array}$ & - & - & - & - & SBR \\
\hline $\begin{array}{c}\text { Mocis frugalis Erebidae } \\
\text { (Fabricius, 1775) }\end{array}$ & - & - & - & - & SBR \\
\hline $\begin{array}{c}\text { Orgyia postica Erebidae } \\
\text { (Walker, 1855) }\end{array}$ & + & + & +- & - & SBR \\
\hline $\begin{array}{c}\text { Thyas honesta Erebidae } \\
\text { Hübner, } 1806\end{array}$ & - & - & -- & - & SBR \\
\hline $\begin{array}{c}{ }^{*} \text { Eupterote hibisci Eupterotidae } \\
\text { Fabricius, } 1775\end{array}$ & + & + & +- & - & SBR \\
\hline $\begin{array}{l}\text { Lophoptera - } \quad \text { Euteliidae } \\
\text { squammigera Guenée, } 1852\end{array}$ & - & - & - & - & SBR \\
\hline $\begin{array}{c}\text { Gonodontis clelia Geometridae } \\
\text { (Cramer, [178o]) }\end{array}$ & - & + & +- & + & $\begin{array}{l}\text { SBR and } \\
\text { And. \& Nico. }\end{array}$ \\
\hline $\begin{array}{c}\text { Hyposidra talaca Geometridae } \\
\text { (Walker, 1860) }\end{array}$ & - & - & - & - & SBR \\
\hline $\begin{array}{c}\text { Streblote siva Lasiocampidae- } \\
\text { (Lefèbvre, 1827) }\end{array}$ & & - & +- & - & SBR \\
\hline $\begin{array}{c}\text { *Altha nivea Limacodidae } \\
\text { Walker, } 1862\end{array}$ & + & + & ++ & + & SBR \\
\hline $\begin{array}{c}\text { Leucania roseilinea Noctuidae } \\
\text { Walker, } 1862\end{array}$ & - & - & -- & - & SBR \\
\hline $\begin{array}{c}\text { *Spodoptera litura Noctuidae } \\
\text { (Fabricius, 1775) }\end{array}$ & + & + & ++ & + & SBR \& Gujarat \\
\hline $\begin{array}{c}\text { Gadirtha pulchra Nolidae } \\
\text { Butler, } 1886\end{array}$ & - & - & $-\quad-$ & - & SBR \\
\hline
\end{tabular}

Abbreviations: Sagar (1), Gosaba (2), Jharkhali (3), Bali (4), Satjelia (5) moths (Table-1; Plate 1 \& 2) have been recorded of which Erebidae found to be the most dominant family with 14 species followed by three families namely Crambidae, Geometridae and Noctuidae each with 02 species and seven families namely Cossidae, Limacodidae, Lasiocampidae, Eupterotidae, Uraniidae, Eutellidae and Nolidae each included only o1 species (Table-1 \& Fig.-2). Only these 27 species came to the light traps. Since the study time was very short emphasis was given to record as many numbers of species as possible. The individuals per species were not recorded during the study.

The cluster analysis has been carried out by the Jaccard analysis method among the six islands namely Sagar, Gosaba, Jharkhali, Bali, Satjelia and Jambudwip of Sundarban Biosphere Reserve. The analysis shows that the maximum similarity in species composition of Jambudwip is with Jharkhali island and vice versa (S \& D index $=0.37$ ) and that of the minimum are with Bali Island and Satjelia Island respectively (S \& D index $=0.22$ ) (Fig.-1).

In the present study, the occurrence of 27 species of moths from Jambudwip has been recorded which shows that majority of the species (15) are not distributed in the human inhabiting islands (Sagar, Gosaba, Jharkhali, Bali and Satjelia) of SBR (Table-1). Rest of 05 species share their occurrence in other five islands of SBR as shown in Table.1. Only four species are found common with other mangroves of India (Veenakumari et al., 1997 \& Remadevi et al., 2008) (Table-1). Since, Jambudwip is an isolated; uninhabited island and the study was exclusively carried out from the mangroves. Therefore these 15 species can be designated as true mangrove inhabiting moths of SBR. Further, five species (marked with * in Table-1) are reported pests of different agricultural plants (Biswas et al., 2016).

Recently, a severe lepidopteran infestation by a wellknown teak defoliator moth species, Hyblaea puera (Cramer) have been reported in mangroves of India (Arun et al., 2012; Chattopadhyay 200o). Similarly, Biswas et al. (2017) reported the same moth species infesting Avicennia alba Blume, one of the major mangrove species in SBR. Interestingly it has been observed that Hyblaea puera (Cramer) in the mangrove ecosystem shows some remarkable adaptations which are different from the populations occurring in the teak plantations. Therefore, it can be presumed that these agricultural pests are gradually adapting to the mangrove ecosystem and making mangroves as their secondary host. The present study is the baseline study for moths of mangrove ecosystem, based on which a further long term study might help to establish moth mangrove relationship.

\section{Acknowledgment:}

Authors are grateful to the Director, Zoological Survey of India for the support and encouragement to carry out the work. Authors are also thankful to Forest Officials to provide the necessary permissions and logistic support for undertaking this surveys. 


\section{References:}

Arora, G.S. (1986): On methods of collection and preservation of Lepidoptera, pp. 109-120. In: Tikader, B.K. (ed.) Manual: Collection, Preservation On methods of Collection and Preservation of Lepidoptera, and Identification of Insects and Mites of Economic Importance. Pub. by: Zoological Survey of India, Kolkata, India.

Arun, P.R. \& Mahajan, M.V. (2012): Ecological costs and benef its of teak defoliator (Hyblaea puera Cramer) outbreaks in a mangrove ecosystem. Marine Sci., 2(5):48-51.

Biswas, O., Modak, B.K., Mazumder, A. \& Mitra, B. (2016): Moth (Lepidoptera: Heterocera) diversity of Sunderban Biosphere Reserve, India and their pest status to economically important plants. J. Entomol. Zool. Stud., 4(2):13-19.

Biswas, O., Panja, B., Garain, P.K., Shah, S.K., Modak, B.K., \& Mitra, B. (2017): Hyblaea puera (Cramer, 1777) [Lepidoptera: Heterocera: Hyblaeidae] infestation on Avicennia alba Blume in Sunderban Biosphere Reserve, West Bengal, India. Proc. Zool.Soc., 71(4):331-335.

Cannicci, S., Burrows, D., Fratini, S., Smith, T.J., Offenberg, J. \& Dahdouh-Guebas, F. (2008): Faunal impact on vegetation structure and ecosystem function in mangrove forests: A review. Aquatic Bot., 89(2):186-200

Chattopadhyay, S. (2000): Observation on the feeding habit of the teak defoliator, Hyblaea puera Cramer (Hyblaeidae: Lepidoptera).J. Interacademicia, 4(1):183-185.

Hampson, G.F. (1892): Fauna of British India including Ceylon and Burma (Moths), Vol. I. Pub. by: Taylor \& Francis, London, $527 \mathrm{p}$.

Hampson, G.F. (1894). Fauna of British India including Ceylon and Burma (Moths), Vol. II. Pub. by: Taylor \& Francis, London, 6o9p.

Hampson G.F. (1895). Fauna of British India including Ceylon and Burma (Moths), Vol. III. Pub. by: Taylor \& Francis, London, $546 \mathrm{p}$.

Hampson G.F. (1896). Fauna of British India including Ceylon and Burma (Moths), Vol. IV. Pub. by: Taylor \& Francis, London, 594p.
Holloway, J.D. (1988): The Moths of Borneo (Arctiidae, Syntomiinae, Euchromiinae, Arctiinae, Aganainae to Noctuidae). Malayan Nat. J., 6:1-101.

Holloway, J.D. (1988): The Moths of Borneo: Family Arctiidae, Subfamilies Syntominae, Euchromiinae, Arctiinae; Noctuidae misplaced in Arctiidae (Camptoloma, Aganainae). Pub. by: Malaysian Nature Society.

Holloway, J.D. (1999): The Moths of Borneo (Lymantriidae). Malayan Nat. I, 5:1-188.

Holloway J.D. (2001). The Moths of Borneo (Arctiidae: Lithosiinae). Malayan Nat. I., 7:279-486.

Chandra, K., Alfred, J.R.B., Mitra, B. \& Roy Chowdhury, B. (2017): Fauna of Sundarban Biosphere Reserve. Pub. by: Zoological Survey of India, India. P. 240.

Mitra, B. (2017): Insect faunal diversity and their ecosystem services in Sundarban Biosphere Reserve, pp. 137-173. In, Chandra, K., Alfred, J.R.B., Mitra, B. \& Roy Chowdhury, B. (eds.) Fauna of Sundarban Biosphere Reserve. Pub. by: Director, Zoological Survey of India.

Mitra, B., Shah, S.K. \& Biswas, O. (2019). Insecta: Lepidoptera Butterflies and Moths, pp. 285-316. In, Faunal Diversity of Mangrove Ecosystem in India. Pub. by: Zoological Survey of India, India.

Saha, R. \& Mitra, B. (2017): Bengalian Rain forest to Sundarban Biosphere Reserve-A Journey towards conservation, pp. 6-16. In, Chandra, K., Alfred, J.R.B., Mitra, B. \& Roy Chowdhury, B. (eds.) Fauna of Sundarban Biosphere Reserve. Pub. by: Zoological Survey of India, India.

Remadevi, O.K., Latheef, A., Chatterjee, D. \& Raji, B. (2008): Entomofauna of mangrove ecosystem of India - an annotated check list. Biosystematica, 2(2):33-80

Veenakumari, K., Mohanraj, P. \& Bandyopadhyay, A.K. (1997): Insect herbivores and their natural enemies in mangals of the Andamans and Nicobars Islands. J. Nat. His., 31(7): 11051126. 